\title{
ANALISIS KELAYAKAN LAHAN PERUNTUKAN PEMBANGUNAN DERMAGA PLTU DI PERAIRAN DESA SUKADANA KECAMATAN BAYAN LOMBOK UTARA
}

\author{
${ }^{1}$ Sukuryadi, ${ }^{2}$ Mas'ad \\ ${ }^{1,2}$ Dosen Program Studi Pendidikan Geografi, Universitas Muhammadiyah Mataram \\ Email : Syukur_y80@yahoo.com
}

\begin{abstract}
ABSTRAK
Pengelolaan wilayah pesisir dan pantai perlu dikembangkan perencanaannya sebagai langkah awal dalam pencapaian hasil yang optimal. Tujuannya adalah untuk mengoptimalkan keuntungan-keuntungan yang disediakan oleh kawasan pesisir dan untuk meminimalkan konflik serta berbagai perusakan yang dilakukan oleh manusia di dalam wilayah pesisir. Guna mewujudkan hal tersebut, penataan ruang berupa penetapan fungsi zonasi diharapkan dapat menjaga keseimbangan antara perlindungan ekosistem dan eksploitasinya dalam pengelolaan wilayah pesisir dan lautan. Zonasi merupakan upaya penetapan batas-batas fungsional suatu peruntukan sesuai dengan potensi sumberdaya, daya dukung dan proses-proses ekologi yang berlangsung dalam sistem tersebut. Berdasarkan hal tersebut di atas, maka studi penelitian ini dapat menjadi suatu jawaban atas permasalahan itu dalam rangka pengembangan wilayah pesisir dan lautan ditinjau dari pemanfaatan ruang untuk kegiatan pembangunan dermaga PLTU di wilayah pesisir desa Sukadana kecamatan Bayan Lombok Utara. Dengan demikian tujuan penelitian ini untuk mengetahui tingkat kesesuaian perairan laut bayan bagi rencana pembangunan dermaga/pelabuhan PLTU ditinjau dari aspek parameter oceanografinya. Metode yang digunakan dalam penelitian ini adalah metode survey terhadap parameter-parameter oceanografi, kondisi eksisting beberapa parameter oseanografi perairan secara insitu kemudian disandingkan dengan matriks kesesuaian bagi kelayakan peraiaran untuk pembangunan dermaga. Diantara beberapa parameter tersebut adalah; pasang surut, arus, gelombang, bathimetry, dan hal-hal lain yang diperlukan. Berdasarkan hasil analisis data yang dilakukan dalam penelitian ini, maka dapat disimpulkan bahwa potensi kesesuaian lahan wilayah perairan desa Sukadana kecamatan Bayan Lombok Utara untuk pembangunan/pengembangan dermaga PLTU memiliki tingkat kesesuaian yang berbeda-beda sesuai dengan karakteristik parameter lingkungannya, dalam hal ini terbagi menjadi 2 kategori yaitu Sangat Sesuai (S1), dan Sesuai (S2).
\end{abstract}

Kata Kunci: Tingkat Kesesuaian, Dermaga PLTU, Parameter Oceanografi

\section{PENDAHULUAN}

Indonesia dengan letak geografisnya pada jalur katulistiwa dan beriklim tropis telah dikenal sebagai negara kepulauan, mempunyai sumberdaya pesisir dan laut yang sangat besar serta spesifik. Sebagai negara yang mempunyai keuntungan alam berupa tempat megabiodiversity maka pemikiran sungguhsungguh tentang pemanfaatan dan pengelolaannya merupakan suatu langkah tepat dalam mengejar ketertinggalan pembangunan negara ini. Sumber daya alam berupa tropical marine resources, yang hanya dimiliki oleh negara-negara tropis, Indonesia termasuk paling kaya keanekaragaman hayatinya, dalam arti tidak akan tertandingi oleh negara-negara di kawasan subtropis dan negara-negara maju di belahan bumi bagian utara dan selatan. Untuk itu maka perlu adanya arah pemikiran dan kebijkasanaan nasional untuk memanfaatkan marine biodiversity sebagai basis utama kelangsungan produk untuk devisa negara dalam jangka panjang.

Pengelolaan wilayah pesisir harus dilakukan dengan cermat agar manfaat ekonomi dapat diperoleh secara maksimal dan dampak negatif dari pemanfaatannya dapat dikurangi sekecil mungkin. Untuk dapat melakukan pengelolaan sebagaimana dimaksud di atas, maka diperlukan rencana yang memadai. Hal ini dikarenakan bahwa wilayah pesisir merupakan ekosistem yang sangat potensial, namun sangat sensitif pula. Kesalahan dalam pengelolaan dapat menghilangkan potensi manfaat kawasan pesisir, dapat menimbulkan dampak negatif pada wilayah daratan di sekitarnya, dan dapat pula menimbulkan dampak negatif pada wilayah lautan dalam.

Dalam perkembangannya, wilayah pesisir cenderung berkembang dengan pesat. Namun jika potensi sumberdaya tersebut tidak 
dikelola dan dimanfaatkan dengan seoptimal mungkin, maka akan berdampak terhadap kerusakan lingkungan, misalnya abrasi (pengikisan) garis pantai, penebangan hutan bakau, rusaknya terumbu karang, serta tercemarnya badan perairan sekitar wilayah pesisir. Kerusakan lingkungan tersebut pada gilirannya dapat menurunkan produktivitas perairan (populasi perikanan) di wilayah pesisir sehingga dapat mempengaruhi daya tarik pariwisata, khusunya wisata bahari yang dapat berdampak pada penurunan tingkat kesejahteraan masyarakat pesisir.

Munculnya berbagai dampak negatif seperti di atas antara lain disebabkan oleh fungsi ekologis dan fungsi ekonomi wilayah pesisir tidak ditempatkan secara proporsional dalam mempertimbangkan pembangunan dan pemanfaatan lahan wilayah pesisir. Oleh karena itu, untuk tidak memperbesar dampak negatif yang timbul, sejak sekarang perlu ditempuh berbagai langkah yang berorientasi pada pemanfaatan lahan dan sumberdaya pesisir yang bernilai tambah tinggi, tetapi disertai dengan pelestarian fungsi ekologisnya (keseimbangan ekosistem wilayah pesisir).

Untuk itu maka pengelolaan wilayah pesisir dan pantai perlu dikembangkan perencanaan pengelolaan wilayah pesisir sebagai langkah dalam pencapaian hasil yang optimal. Tujuannya adalah untuk mengoptimalkan keuntungan-keuntungan yang disediakan oleh kawasan pesisir dan untuk meminimalkan konflik serta berbagai perusakan yang dilakukan oleh manusia di dalam wilayah pesisir. Guna mewujudkan hal tersebut, penataan ruang berupa penetapan fungsi zonasi diharapkan dapat menjaga keseimbangan antara perlindungan ekosistem dan eksploitasinya dalam pengelolaan wilayah pesisir dan lautan. Zonasi merupakan upaya penetapan batas-batas fungsional suatu peruntukan sesuai dengan potensi sumberdaya, daya dukung dan proses-proses ekologi yang berlangsung dalam sistem tersebut.

Berdasarkan hal tersebut di atas, maka studi penelitian ini dapat menjadi suatu jawaban atas permasalahan itu dalam rangka pengembangan wilayah pesisir dan lautan ditinjau dari pemanfaatan ruang untuk kegiatan pelabuhan di wilayah pesisir Lombok Utara.

Berangkat dari pandangan tersebut diatas, maka untuk mengetahui tingkat kesesuaian perairan laut bayan bagi rencana pembangunan dermaga/pelabuhan PLTU diperlukan kegiatan penelitian khusus tentang sejauh mana kondisi eksisting beberapa parameter oseanografi perairan secara in-situ kemudian disandingkan dengan matriks kesesuaian bagi kelayakan peraiaran untuk pembangunan dermaga. Diantara beberapa parameter tersebut adalah; pasang surut, arus, gelombang, jenis sedimen, bathimetry, kontur ekosistem utama wilyah pesisir dan hal-hal lain yang diperlukan.

\section{METODE PENELITIAN}

A. Waktu dan Lokasi

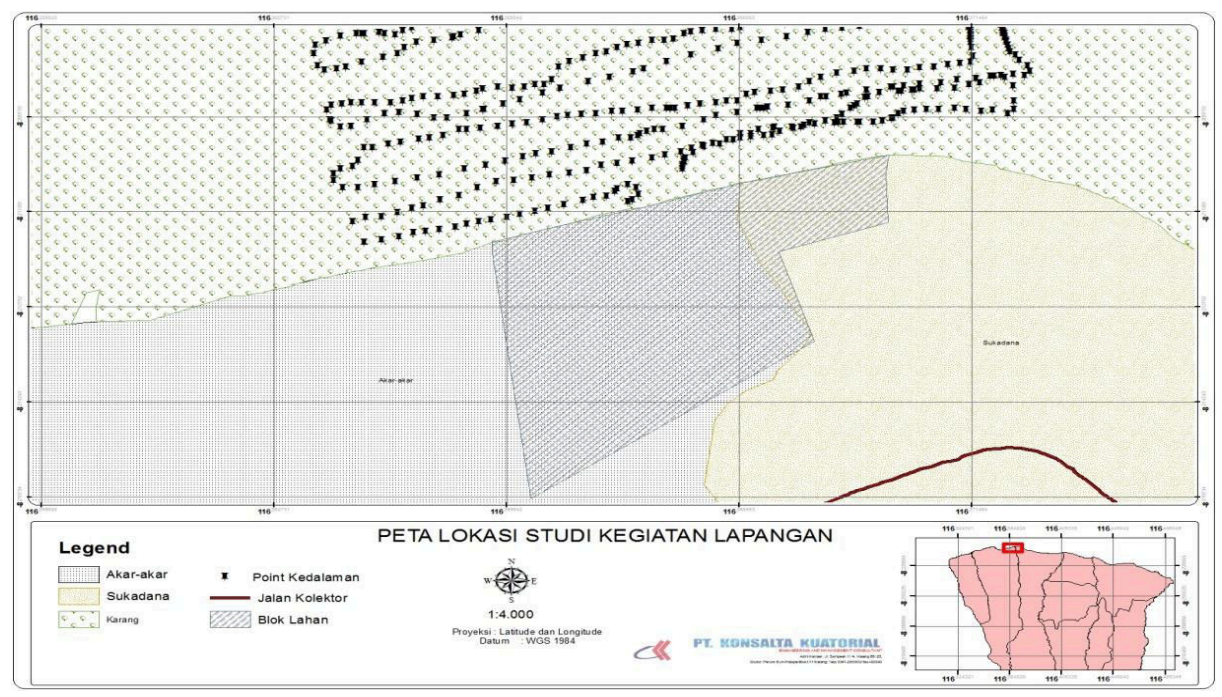

Gambar 1. Peta Lokasi Survey Lapangan 
Pelaksanaan kegiatan penelitian ini adalah pada minggu pertama bulan januari 2015 di perairan Bayan dengan rincian kegiatan sebagai tertera pada Tabel 1 berikutTabel 1 . Jadwal Kegiatan

Tabel 1. Jadwal Kegiatan

\begin{tabular}{|c|c|c|c|c|c|c|c|}
\hline \multirow{2}{*}{ No } & \multirow{2}{*}{ Kegiatan } & \multicolumn{6}{|c|}{ Hari ke-n } \\
\hline & & 12 & 3 & 4 & 5 & 6 & 7 \\
\hline 1 & $\begin{array}{l}\text { Survey dan } \\
\text { Pengukuran } \\
\text { data Lapangan }\end{array}$ & & & & & & \\
\hline 2 & $\begin{array}{l}\text { Pengumpulan } \\
\text { Data Lapangan }\end{array}$ & & & & & & \\
\hline 3 & $\begin{array}{l}\text { Olah dan } \\
\text { Analisa Data }\end{array}$ & & & & & & \\
\hline 4 & $\begin{array}{l}\text { Penyusunan } \\
\text { Laporan Akhir }\end{array}$ & & & & & & \\
\hline 5. & $\begin{array}{l}\text { Penyerahan } \\
\text { hasil pekerjaan }\end{array}$ & & & & & & \\
\hline
\end{tabular}

Penelitian ini dilakukan di perairan Lombok Utara dan dilanjutkan pengolahan data spasial dilakukan di Laboratorium Geografi, Jurusan IPS Fakultas Keguruan dan IImu Pendidikan Universitas Muhammadiyah Mataram (1).

\section{B. Alat dan Bahan}

Tabel 2 Alat-alat yang digunakan dalam pengambilan data lapangan.

\begin{tabular}{clcc}
\hline No & Nama Alat & Jumlah & Kegunaan \\
\hline $\mathbf{1}$ & $\begin{array}{l}\text { Global } \\
\text { Positioning } \\
\text { System (GPS) }\end{array}$ & 1 buah & $\begin{array}{c}\text { Penentu } \\
\text { posisi stasiun } \\
\text { pengamatan }\end{array}$ \\
\hline 2 & Kapal & I buah & $\begin{array}{c}\text { Alat } \\
\text { transportasi }\end{array}$ \\
\hline 3 & $\begin{array}{l}\text { Current } \\
\text { Meter }\end{array}$ & $\mathbf{1}$ buah & $\begin{array}{c}\text { Pengukur } \\
\text { arus dan } \\
\text { Gelombang } \\
\text { dan Pasang } \\
\text { Surut }\end{array}$ \\
\hline $\mathbf{4}$ & GPS MAPS & $\mathbf{1}$ buah & $\begin{array}{c}\text { Pengukur } \\
\text { kedalaman }\end{array}$ \\
\hline 5 & $\begin{array}{l}\text { Kompas } \\
\text { Geologi }\end{array}$ & $\mathbf{1}$ buah & $\begin{array}{c}\text { Penentu } \\
\text { arah }\end{array}$ \\
\hline 6 & Stopwatch & $\mathbf{1}$ buah & $\begin{array}{c}\text { Penentu/me } \\
\text { nghitung }\end{array}$ \\
\hline
\end{tabular}

\begin{tabular}{|c|c|c|c|}
\hline & & & waktu \\
\hline 7 & $\begin{array}{l}\text { Alat Selam } \\
\text { Dasar }\end{array}$ & 1 set & $\begin{array}{c}\text { Pengamatan } \\
\text { Secara } \\
\text { Visual }\end{array}$ \\
\hline 8 & $\begin{array}{l}\text { Kamera Foto } \\
\text { Digital }\end{array}$ & 1 buah & $\begin{array}{c}\text { Dokumentas } \\
\text { i proses }\end{array}$ \\
\hline 9 & $\begin{array}{l}\text { Alat tulis } \\
\text { menulis }\end{array}$ & - & $\begin{array}{c}\text { Pencatatan } \\
\text { hasil } \\
\text { pengukuran }\end{array}$ \\
\hline 10 & $\begin{array}{l}\text { Software } \\
\text { pengolah data } \\
\text { (MS Excel) }\end{array}$ & 1 buah & $\begin{array}{l}\text { Mengolah } \\
\text { data }\end{array}$ \\
\hline 11 & $\begin{array}{l}\text { Software } \\
\text { analisa data } \\
\text { GIS (ArcView, } \\
\text { ArcGIS, } \\
\text { Surfer dll }\end{array}$ & 1 buah & $\begin{array}{l}\text { Mengolah } \\
\text { data }\end{array}$ \\
\hline
\end{tabular}

Sedangkan sebagai bahan yang digunakan antara lain Peta Rupa Bumi skala 1 : 50.000.

\section{Prosedur Penelitian}

\section{Tahap awal/persiapan}

Tahap awal penelitian ini adalah untuk mempersiapkan segala sesuatu yang berhubungan dengan proses penelitian ini, persiapan yang dilakukan berupa pengumpulan referensi dan literatur pendukung, dan pengumpulan data awal penunjang penelitian ini.

\section{Observasi lapangan dan penentuan objek penelitian \\ Observasi lapangan dilakukan untuk} memperoleh gambaran kondisi umum wilayah penelitian (gambar 1). Selanjutnya dapat ditentukan tentang kriteria-kriteria yang akan dijadikan dasar dari penelitian ini.

\section{Pengumpulan data}

Data-data yang dikumpulkan ada dua macam yaitu data sekunder daerah penelitian dan data survei lapangan yang antara lain mencakup data fisika-kimia oseanografi yaitu :

a. Pengukuran Arah dan Kecepatan Arus Pengukuran kecepatan arus dilakukan dengan menggunakan current meter, sedangkan arah arus ditentukan dengan menggunakan kompas geologi

b. Pengukuran kedalaman

Pengukuran kedalaman menggunakan GPS MAPS yang ditenggelamkan dibawah lunas kapal 
c. Pengukuran Arah dan Tinggi Gelombang Pengambilan data dilakukan dengan menggunakan Current Meter. Penentuan data gelombang yang terdiri dari tinggi gelombang signifikan $(\mathrm{H} 1 / 3)$, perode gelombang $(\mathrm{T})$, dan periode gelombang signifikan (T1/3) (Pratiko, 1996 dalam Saleng, 2000) yang selengkapnya di hitung dengan rumus sebagai berikut :

1. Tinggi gelombang signifikan $(\mathrm{H} 1 / 3)$

$$
\mathrm{H} \frac{1}{3}=\frac{1}{3} \sum_{\mathrm{N}}^{\mathrm{N}=1}\left[\mathrm{H} 1+\mathrm{H} 2+\ldots \mathrm{H}_{\mathrm{N}}\right]
$$

Keterangan :

$\mathrm{H} \frac{1}{3}$ = Tinggi gelombang signifikan (m)

$N=\frac{1}{3}$ jumlah gelombang terukur

2. Periode Gelombang ( $\mathrm{T})$

$$
\mathrm{T}=\frac{\mathrm{t}}{\mathrm{T}}
$$

Keterangan :

$\mathrm{T}=$ Periode gelombang hasil pengukuran (dtk)

$\mathrm{t}=$ Waktu pengamatan ( $\mathrm{dtk})$

$\mathrm{N}=$ Banyaknya gelombang

3. Periode gelombang signifikan $\left(T \frac{1}{3}\right)$

$$
\mathrm{T} \quad \frac{1}{3}=1,1 \times \mathrm{T}
$$

Keterangan ;

$\mathrm{T}=$ Pediode gelombang (dtk)

$\mathrm{T} \frac{1}{3}=$ Periode signifikan (dtk)

d. Pengukuran Pasang surut

Pengambilan data dilakukan dengan menggunakan Current Meter untuk mengetahui kisaran dan type pasang surut di lokasi kegiatan

\section{Analisa Data}

1. Arus

Data arus umumnya cukup sulit diperoleh kecuali melakukan pengukuran secara langsung dilapangan. Dalam studi ini arus yang dibutuhakan merupakan pola arus permukaan secara spasial di wilayah studi. Perolahan data arus permukaan secara spasial di wilayah studi sangat sulit dilakukan dan mebutuhkan waktu yang lama. Untuk memperoleh data pola arus permukaan dilakukan pemodelan numerik dengan menggunakan model DHI MIKE 21. Model ini menggunakan pendekatan metode beda hingga (finite difference) untuk menyelesaikan persamaan yang digunakan. Adapun persamaan yang digunakan adalah sebagai berikut:

Persamaan kontinuitas:

$$
\frac{\partial \zeta}{\partial t}+\frac{\partial p}{\partial x}+\frac{\partial q}{\partial x}=\frac{\partial d}{\partial t}
$$

Persamaan momentum pada sumbu $\mathrm{x}$

$$
\begin{aligned}
\frac{\partial p}{\partial t}+\frac{\partial}{\partial x}\left(\frac{p^{2}}{h}\right)+ & \frac{\partial}{\partial y}\left(\frac{p q}{h}\right)+g h \frac{\partial \zeta}{\partial x}+\frac{g p \sqrt{p^{2}+q^{2}}}{C^{2} \cdot h^{2}} \\
& -\frac{1}{\rho_{w}}\left[\frac{\partial}{\partial x}\left(h \tau_{x x}\right)+\frac{\partial}{\partial y}\left(h \tau_{x y}\right)\right] \\
& -\Omega_{\mathrm{q}}-f V V_{x}+\frac{h}{\rho_{w}} \frac{\partial}{\partial x}\left(\rho_{a}\right)=0
\end{aligned}
$$

Persamaan momentum pada sumbu y

$$
\begin{aligned}
\frac{\partial q}{\partial t}+\frac{\partial}{\partial y}\left(\frac{q^{2}}{h}\right)+\frac{\partial}{\partial x}\left(\frac{p q}{h}\right)+ & g h \frac{\partial \zeta}{\partial y}+\frac{g p \sqrt{p^{2}+q^{2}}}{c^{2} \cdot h^{2}} \\
-\frac{1}{\rho_{w}}\left[\frac{\partial}{\partial y}\left(h \tau_{y y}\right)\right. & \left.+\frac{\partial}{\partial x}\left(h \tau_{x y}\right)\right]+\Omega_{\mathrm{p}}-f V V_{y} \\
& +\frac{h}{\rho_{w}} \frac{\partial}{\partial y}\left(\rho_{a}\right)=0
\end{aligned}
$$

dimana:

$$
\begin{array}{ll}
h(x, y, t) & : \text { water depth }(=\zeta-d) \\
d(x, y, t) & : \text { kedalaman yang bervariasi } \\
& \text { terhadap waktu } \\
\zeta(x, y, t) & : \text { surface elevation } \\
p, q(x, y, t) & : \text { flux densitas pada sumbu } \mathrm{x} \\
& \text { dan } \mathrm{y}\left(\mathrm{m}^{3} / \mathrm{s} / \mathrm{m}\right)=(u h, v h) \\
u, v & \text { kecepatan yang dirata-ratakan } \\
& \text { terhadap kedalaman pada } \\
& \text { sumbu } \mathrm{x} \text { dan y } \\
C(x, y) & : \text { Chezy resistance }\left(\mathrm{m}^{1 / 2} / \mathrm{s}\right) \\
g & : \text { gravitasi }\left(\mathrm{m}^{2} / \mathrm{s}\right) \\
f(\mathrm{~V}) & : \text { faktor gesekan angin } \\
\mathrm{V}, \mathrm{Vx}, \mathrm{Vy}(\mathrm{x}, \mathrm{y}, \mathrm{t}): \text { kecepatan angin pada sumbu } \mathrm{x} & \text { dan y (m/s) } \\
\Omega(\mathrm{x}, \mathrm{y}) & : \text { parameter coriolis } \\
\rho_{\mathrm{a}}(\mathrm{x}, \mathrm{y}) & : \text { tekanan atmosfer }(\mathrm{kg} / \mathrm{m} / \mathrm{s} 2) \\
\rho_{\mathrm{w}} & : \text { densitas air laut }(\mathrm{kg} / \mathrm{m} 3) \\
\tau_{\mathrm{xx}}, \tau_{\mathrm{xy}}, \tau_{\mathrm{yy}} & : \text { komponen shear stress efektif }
\end{array}
$$


Bed shear stress pada arah $\mathrm{x}$ dan $\mathrm{y}$ dapat dihitung dengan :

$$
\begin{aligned}
& \tau_{\mathrm{bx}}=\rho \mathrm{c}_{\mathrm{f}} \mathrm{U} \sqrt{\mathrm{U}^{2}+\mathrm{V}^{2}}\left[1+\left(\frac{\partial \mathrm{z}_{\mathrm{b}}}{\partial \mathrm{x}}\right)^{2}+\left(\frac{\partial \mathrm{z}_{\mathrm{b}}}{\partial \mathrm{y}}\right)^{2}\right]^{\frac{1}{2}} \\
& \tau_{\text {by }}=\rho \mathrm{c}_{\mathrm{f}} \mathrm{V} \sqrt{\mathrm{U}^{2}+\mathrm{V}^{2}}\left[1+\left(\frac{\partial \mathrm{z}_{\mathrm{b}}}{\partial \mathrm{x}}\right)^{2}+\left(\frac{\partial \mathrm{z}_{\mathrm{b}}}{\partial \mathrm{y}}\right)^{2}\right]^{\frac{1}{2}}
\end{aligned}
$$

dimana $c_{f}$ adalah koefisien gesekan dan dapat dihitung sebagai berikut :

$$
c_{f}=\frac{g}{C^{2}}=\frac{g^{2}}{\lambda^{2} H^{1 / 3}}
$$

dimana

$C$ : Chezy Koefisien

$n$ : Manning Koefisien

$\lambda:$ 1,486 untuk unit Inggris dan 1,0 untuk SI

Kedalaman rata-rata gesekan turbulen dapat dihitung menggunakan konsep viskositas Eddy dari Boussinesq, yaitu :

$$
\begin{aligned}
& \tau_{\mathrm{xx}}=\rho \mathrm{v}_{\mathrm{xx}}\left(\frac{\partial \mathrm{U}}{\partial \mathrm{x}}+\frac{\partial \mathrm{U}}{\partial \mathrm{x}}\right) \\
& \tau_{\mathrm{xy}}=\tau_{\mathrm{yx}}=\rho \mathrm{v}_{\mathrm{xy}}\left(\frac{\partial \mathrm{U}}{\partial \mathrm{y}}+\frac{\partial \mathrm{V}}{\partial \mathrm{x}}\right)
\end{aligned}
$$

$$
\begin{aligned}
\tau_{\mathrm{yy}}=\rho \mathrm{v}_{\mathrm{yy}}\left(\frac{\partial \mathrm{V}}{\partial \mathrm{y}}+\frac{\partial \mathrm{V}}{\partial \mathrm{y}}\right) \\
\text { dimana, } v \text { adalah } 0,3 \pm 0,6 U^{*} H \\
\mathrm{~V} \quad: \text { Kecepatan arus pada arah } \mathrm{y} \\
\mathrm{U} \quad: \text { Kecepatan arus pada arah } \mathrm{x}
\end{aligned}
$$

\section{Kesesuaian Lahan}

Proses dan tahapan selanjutnya adalah melakukan analisa data dengan SIG (system informasi geografis) yang berbasis pada analisis data spasial dan deskriptif/tabular yang bertujuan untuk menentukan kesesuaian lahan/kawasan perairan eksisting. Data-data (hasil survei dan data sekunder) ini selanjutnya akan di analisis dalam software GIS, analisis dilakukan dengan memasukkan data survei dalam peta dasar melalui sistem overlay data pada setiap peubah/kriteria dengan mempertimbangkan pembobotan dan skala penilaian untuk mendapatkan nilai skoring dalam menentukan kesesuaian lahan/kawasan yang akan menghasilkan suatu peta kesesuaian dan prospektif pengelolaan sumberdaya pesisir/laut termasuk didalamnya bagi

\begin{tabular}{|c|c|c|c|c|}
\hline \multirow{2}{*}{ Faktor } & \multirow{2}{*}{ Simbol } & \multicolumn{3}{|c|}{ KELAS KESESUAIAN LAHAN } \\
\hline & & S1 & S2 & $\mathrm{N}$ \\
\hline Kedalaman & $\mathrm{D}(\mathrm{m})$ & $\mathrm{D}>5,5$ & & $D<5,5$ \\
\hline $\begin{array}{l}\text { Kisaran } \\
\text { Pasang Surut }\end{array}$ & $A(m)$ & $A<2$ & $2<A<4$ & $A>4$ \\
\hline $\begin{array}{l}\text { Kisaran } \\
\text { Laut }\end{array}$ & $\mathrm{V}(\mathrm{m} / \mathrm{s})$ & $V<0,5$ & $0,5<V<1$ & $V>1$ \\
\hline $\begin{array}{l}\text { Tinggi Ombak } \\
\text { Luas areal }\end{array}$ & $\begin{array}{l}\mathrm{H}(\mathrm{m}) \\
\mathrm{L}(\mathrm{m} 2)\end{array}$ & $\begin{array}{c}H<0,2 \\
L<126.000\end{array}$ & $0,2<\mathrm{H}<1,2$ & $\begin{array}{c}H>1,2 \\
L<40.000\end{array}$ \\
\hline
\end{tabular}
pembangunan dermaga/pelabuhan.

Kriteria kesesuaian dapat dikelompokkan ke dalam beberapa aspek, kriteria teknis yang menyangkut kesesuaian dilihat dari aspek fisik yang meliputi beberapa aktivitas utama pada kawasan pesisir sebagai pelabuhan.

Tabel 3 Matriks Kesesuaian Untuk Dermaga

Sumber : Mappadjantji (2001)

\section{PEMBAHASAN}

\section{A. Bathimetri}

Dari Hasil pemeruman batimetri dan tumpang tindih dengan peta batimetri dishidros, didapatkan bahwa batimetri pada lokasi kajian cenderung bersifat landai yang di mulai dari kedalaman sekitar 5 meter di dekat pantai dan semakin dalam ke arah laut lepas. Kondisi pantai yang landai umumnya terdapat pada 
bagian atas kiri dari lokasi kajian, pada bagian sebelah kanan lokasi kajian terdapat tubir (slope) yang memiliki kedalaman lebih dari 100 $\mathrm{m}$ dan rata-rata kedalaman lokasi kajian mencapai 25,7 m, kondisi ini sangat layak untuk dijadikan sebagai lokasi pelabuhan karena syarat pendirian pelabuhan adalah perairan memiliki kedalaman rata-rata lebih dari $5 \mathrm{~m}$.

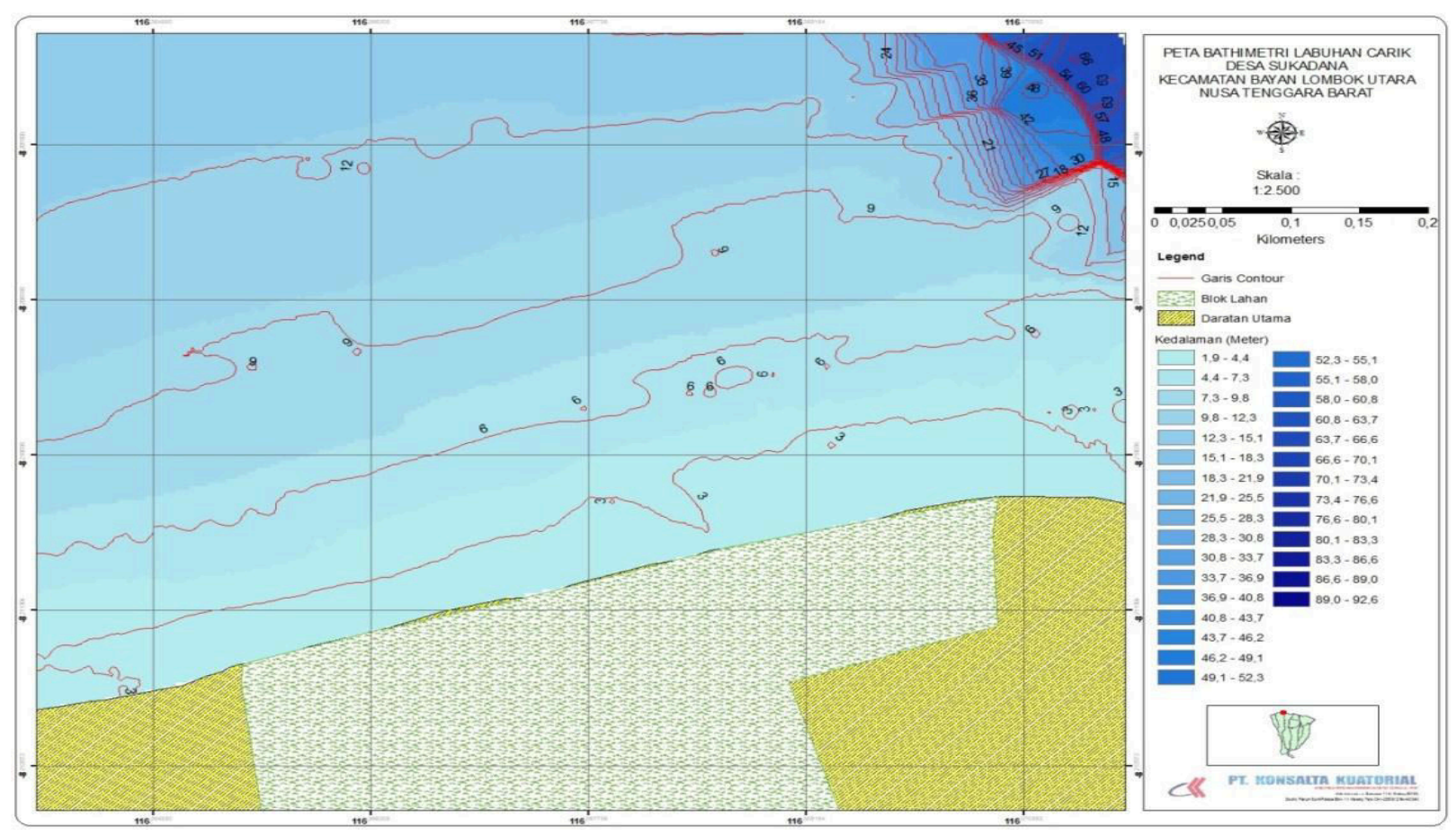

\section{Gambar 2. Peta Batimetri lokasi studi}

\section{B. Arus}

Untuk mengetahui karakteristik pola arus di lokasi kajian, maka di lakukan pedekatan dengan simulasi pemodelan baik secara temporal dan spasial. Simulasi pemodelan dilakukan pada dua musim yaitu musim barat (diwakili bulan Januari) dan musim timur (diwakili bulan Juli). Pengambilan dua musim ini didasarkan atas pertimbangan kondisi wilayah kajian yang sangat dipengaruhi oleh dinmaika yang sangat kontras pada kedua musim tersebut. Hasil simulasi pemodelan di cuplik pada empat kondisi pasang surut yang dianggap ekstrim mempengaruhi pola gerak air yaitu kondis menjelang pasang, saat pasang, menjelang surut, dan saat surut. Hasil model disajikan dalam bentuk gambar vektor yang dioverlay dengan kontur kedalaman perairan.

\section{Arus Musim Barat}

Hasil simulasi model pola arus bulan Januari (musim barat) disajikan pada waktu menjelang pasang, saat pasang, menjelang surut, dan saat surut. Keempat kondisi arus tersebut masing-masing disajikan dalam gambar 2. Secara umum dinamika arus yang didapatkan pada lokasi kajian mirip dengan yang digambarkan pada arus di Lombok Utara secara umum.

Dari Error! Reference source not found. terlihat bahwa tidak terjadi perbedaan pola arus yang nyata baik pada saat waktu saat surut, menjelang pasang, saat pasang, dan menjelang surut. Secara keseluruhan arus cenderung menuju ke arah timur sesuai dengan arah tiupan angin. Pada lokasi kajian dapat dilihat bahwa faktor angin lebih dominan menentkan arah arus dibandingkan dengan pasang surut, hal ini sangat wajar terjadi karena kondisi wilayah studi yang berhadapan langsung dengan laut flores dan cenderung terbuka terhadap tiupan angin pada saat musim barat. Kecepatan arus di sekitar pantai lokasi studi pada saat surut, menjelang pasang, saat pasang, dan menjelang 
surut berkisar antara 0.2-0.25 m/s. kecepatan arus pada musim barat saat surut, menjelang pasang, saat pasang, dan menjelang surut ini di

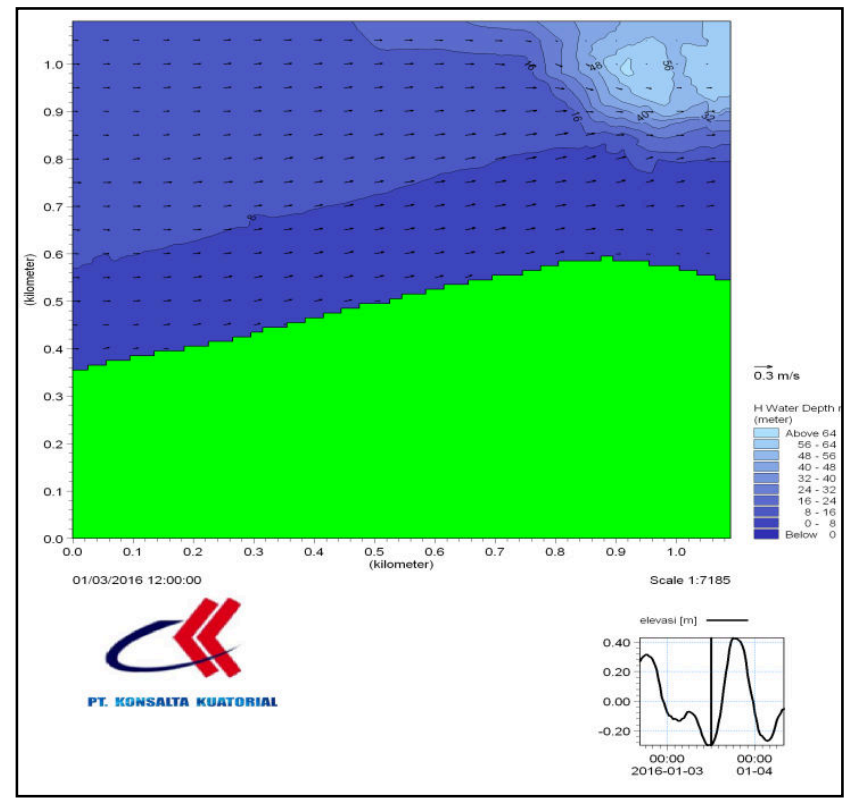

a. Pola Arus musim barat saat surut

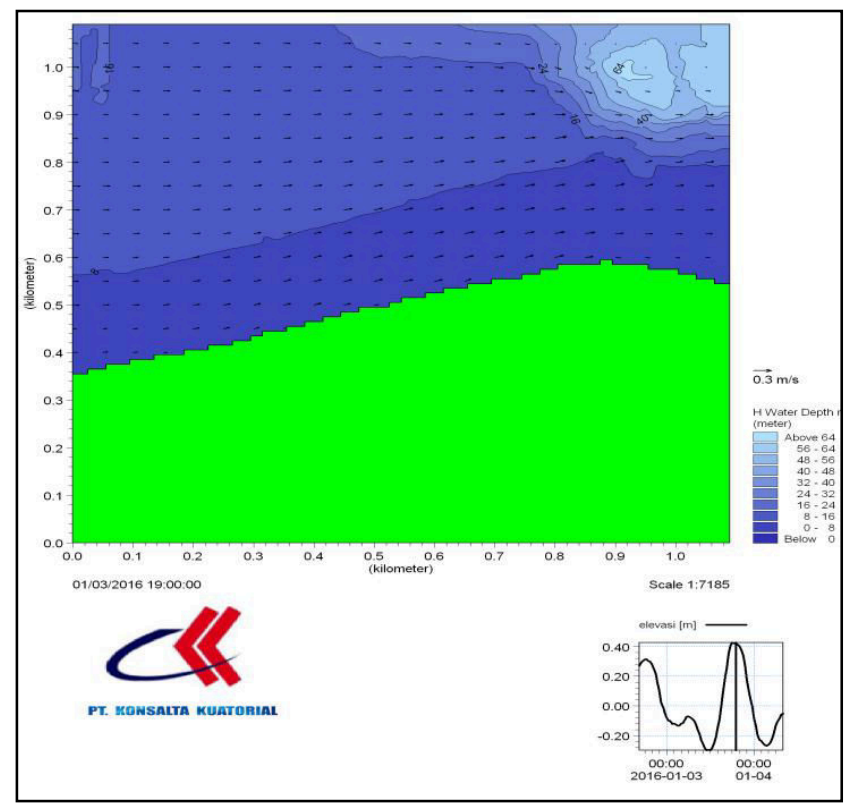

c. Pola Arus musim barat saat pasang bawah dari $0.5 \mathrm{~m} / \mathrm{s}$ sehingga cocok untuk dijadikan sebagai tempat pelabuhan.

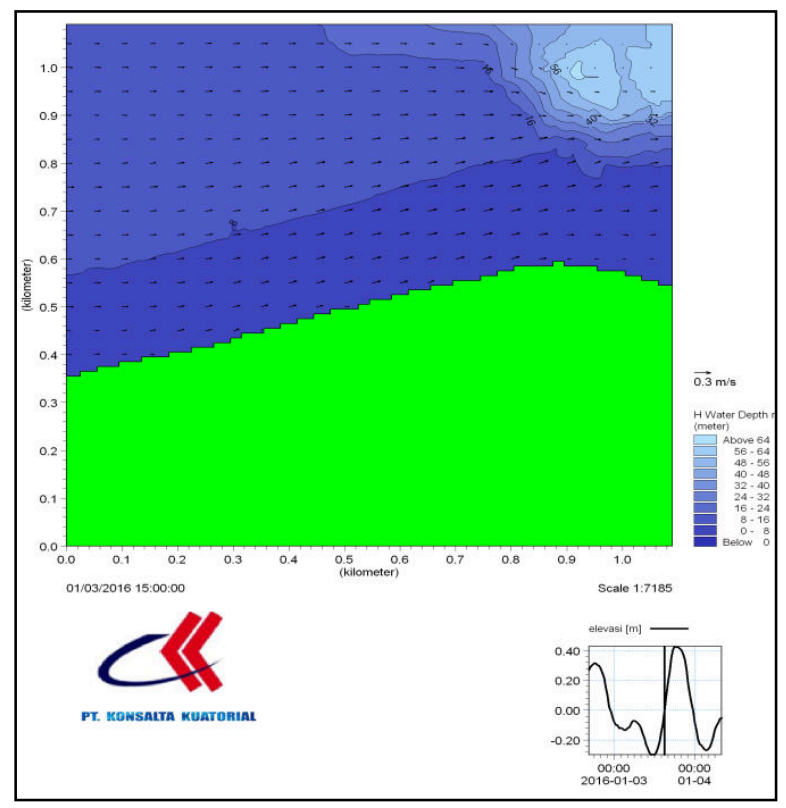

b. Pola Arus musim barat menjelang pasang

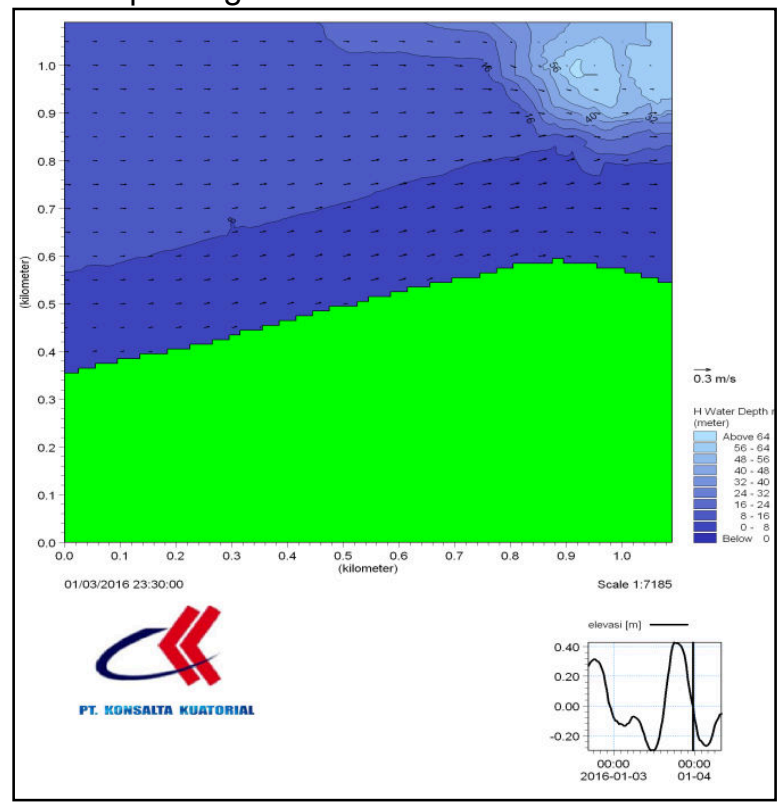

d. Pola Arus musim barat menjelang surut

Gambar 3. Pola Arus Musim Barat

\section{Arus Musim Timur}

Hasil simulasi model pola arus bulan Juli (musim timur) disajikan seperti halnya pada musim barat, yaitu dilakukan pencuplik pada waktu surut, menjelang pasang, saat pasang, dan menjelang surut. Keempat kondisi arus tersebut masing-masing disajikan dalam Gambar 4. Dari keempat gambar tersebut 
terlihat pola arus pada musim timur menunjukkan perbedaan yang nyata bila dibandingkan dengan kondisi musim barat. Pada saat musim timur kecepatan arus berkisar antara $0.05-0.2 \mathrm{~m} / \mathrm{s}$ di dekat pantai. Kecepatan ini lebih kecil dibandingkan kecepatan arus musim barat, hal ini diduga karena lokasi kajian yang cenderung tertutup dari arah tiupan angin saat musim timur yang berasal dari arah daratan. Arah arus musim timur dominan ke arah barat sesuai arah tiupan angin, hal ini mennjukkan bahwa faktor angin di lokasi kajian

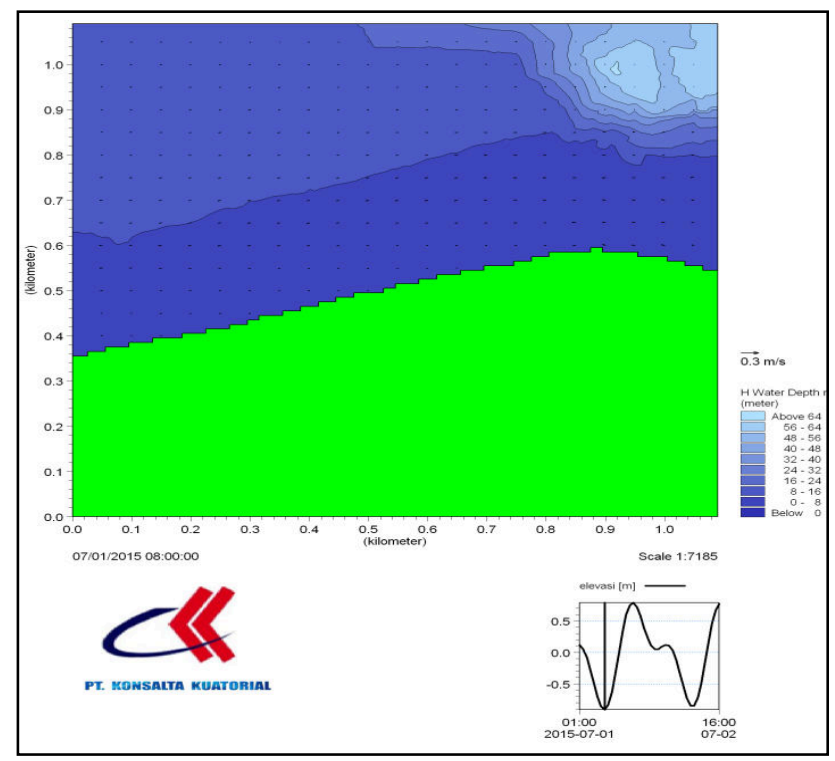

a. Pola Arus musim timur saat surut

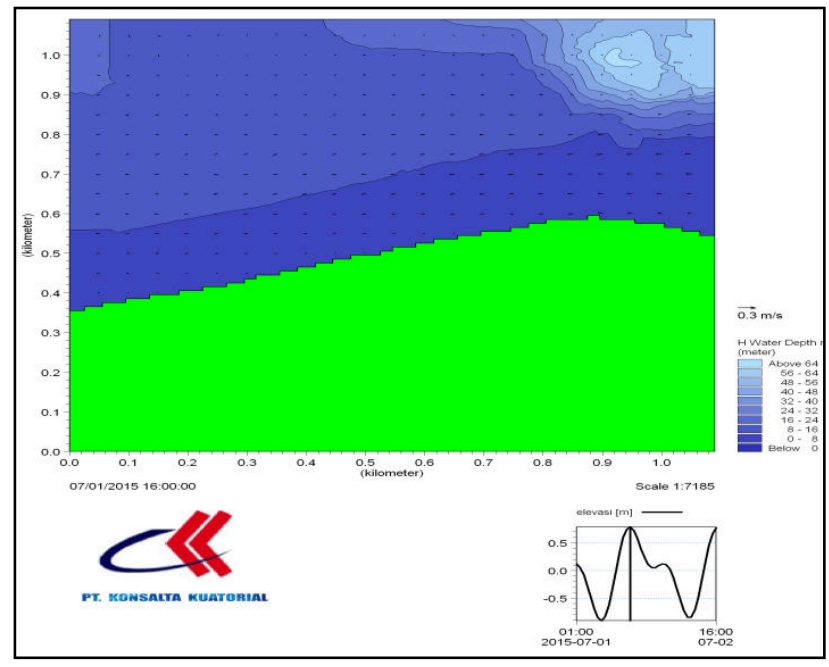

c. Pola Arus musim timur saat pasang memberikan pengaruh yang lebih nyata terhadap pergerakan arus di bandingkan pasang surut. Dalam kajian di Lombok utara yang lebih luas, faktor pasang surut menentukan arah arus, namun jika difokuskan ke lokasi kajian maka faktor angin yang dominan. Hal ini terjadi karena perbedaan luasan wilayah kajian. Pada saat musim timur kecepatan rata-rata arus hanya 0.1 $\mathrm{m} / \mathrm{s}$ yang berarti lokasi kajian sangat sesuai untuk pembangunan pelabuhan karena kecepatannya kurang dari 0.5

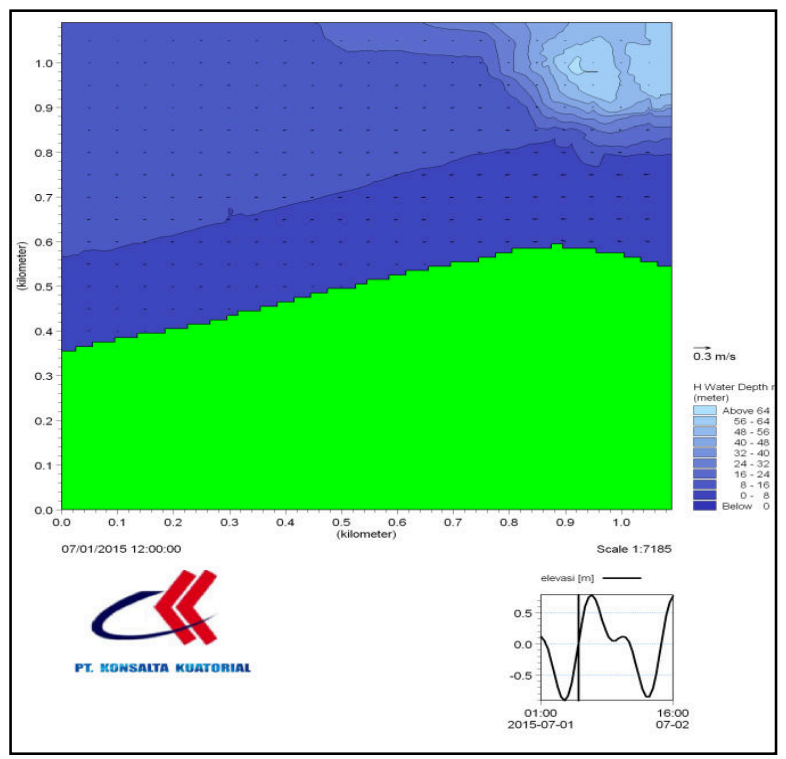

b. Pola Arus musim timur menjelang pasang

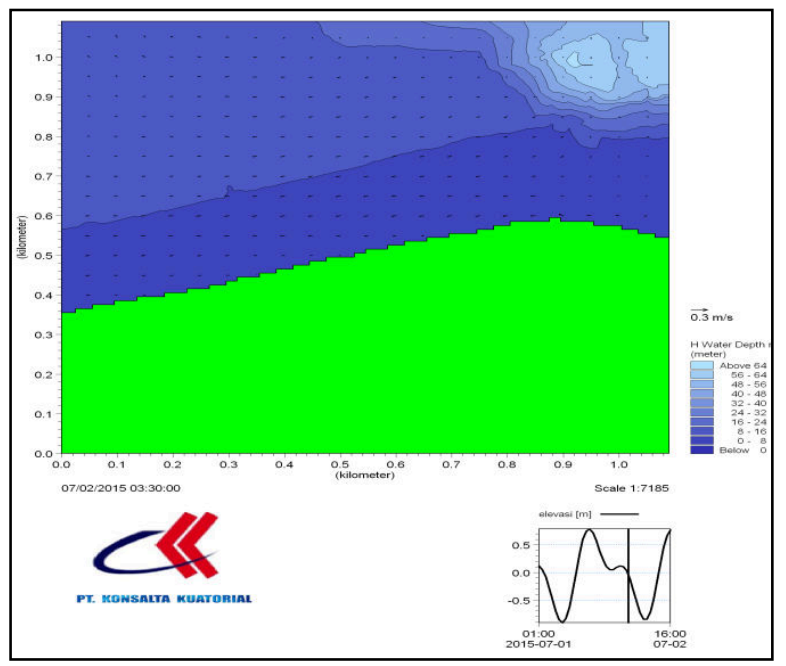

d. Pola Arus musim barat menjelang surut

Gambar 4. Pola Arus Musim Timur 


\section{Gelombang}

Hasil analisis pengukuran gelombang didapatkan bahwa tinggi gelombang signifikan $\left(\mathrm{H}_{1 / 3}\right)$ pada lokasi penelitian adalah $0.292 \mathrm{~m}$, nilai gelombag signifikan yang diperoleh menunjukkan kategori cukup sesuai untuk pembangunan dermaga. Dengan demikian keadaan gelombang signifikan dilokasi dikategrikan sedang hal ini didukung oleh pernyataan Djurdjani (1998) yang mengatakan bahwa Gelombang dikategorikan tenang jika tingginya $<0,20 \mathrm{~m}$, Sedang jika tingginya $0,2-$ $0,50 \mathrm{~m}$, dan besar jika tingginya $>0,50$. Adapun kecepatan gelombang adalah $8,06 \mathrm{~m} / \mathrm{s}$, sedangkan energi gelombang adalah 109,376 $\mathrm{N} / \mathrm{m}^{2}$ yang menunjukkan adalah fluktuasi energi gelombang yang menghempas pantai. Fluktuasi energi gelombang sangat dipengaruhi oleh faktor musim. Pada musim angin timur menunjukkan bahwa energy gelombang yang menghempas pantai sangat lemah karena pada musim ini angin yang bertiup sangat lemah sehingga sehingga gelombang yang terbentuk akibat tenaga angin sangat kecil, namun sebaliknya, ketika musim barat tinggi ombak signifikan yang terbentuk dikategorikan cukup besar karena pada musim ini angin bertiup sangat lebih besar yang berimplikasi terhadap
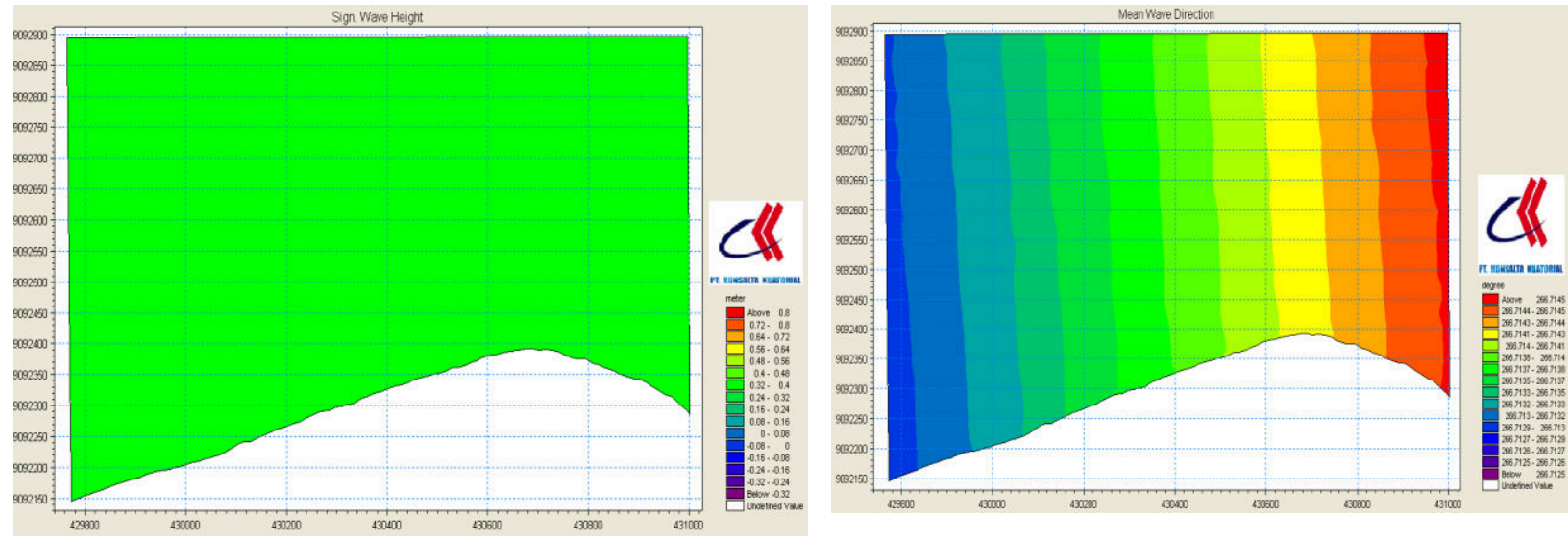

besarnya energy gelombang yang menghempas pantai.

2.2. Hasil pemodelan gelombang pada saat musim barat didapatkan rata-rata tinggi gelombang signifikan sebesar $0.35 \mathrm{~m}$ dan arah 266.7 derajat, sedangkan pada musim timur didapatkan rata-rata tinggi gelombang signifikan sebesar $0.30 \mathrm{~m}$ dan 132 derajat (

Gambar 4). Tinggi gelombang signifikan musim barat lebih tinggi dibandingkan musim timur karena pada saat musim barat lokasi cenderung lebih terbuka terhadap tiupan angin sehingga transfer energi dari angin ke air untuk membentuk gelombang menjadi lebih besar, sedangkan pada musim timur terjadi kondisi sebaliknya. Selain itu fetch gelombang pada saat musim timur lebih kecil dibandingkan saat musim barat, sehingga gelombang yang ditimbulkan juga menjadi lebih kecil. Arah gelombang di lokasi kajian cenderunh mengikuti arah tiupan angin, hal ini terjadi karena gelombang sendiri terbentuk akibat adanya tiupan angin.

\section{Gambar 5 (a). Peta tinggi (atas) dan arah (bawah) gelombang signifikan musim barat}



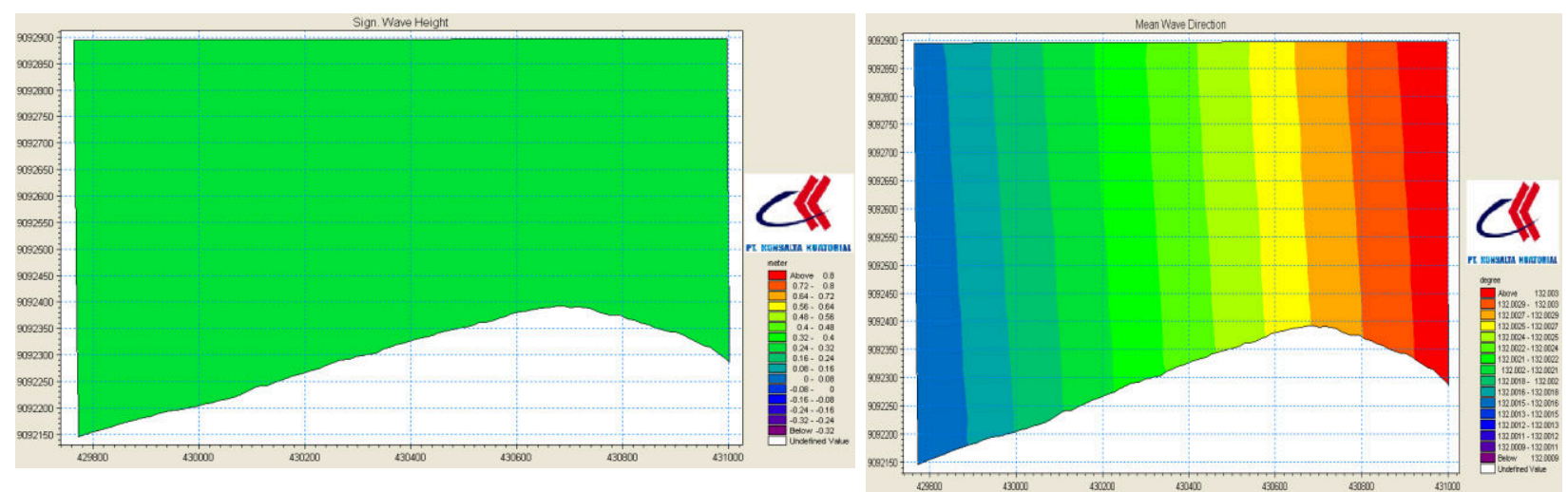

Gambar 5 (b). Peta tinggi (atas) dan arah (bawah) gelombang signifikan musim timur

Hasil simulasi saat musim barat dan musim timur menunjukkan kecenderungan tinggi dan arah gelombang signifikan memiliki ketinggian dan arah yang hampir sama di lokasi dekat panatai maupun yang agak jauh dari pantai, hal ini di duga karena struktur dari perairan yang cenderung landai sehingga tinggi gelombang pada setiap lokasi tidak terlalu jauh berbeda. pengukuran di lapangan menunjukkan ketinggian gelombang signifikan di lokasi kajian kurang dari $0,5 \mathrm{~m}$ sehingga sangat layak dijadikan pelabuhan.

Secara umum energi gelombang yang menghempas pantai sangat dipengaruhi oleh ekosistem dasar perairan, dalam hal ini ekosistem terumbu karang dan padang lamun. Keberadaan Terumbu karang dan padang lamun dilokasi memberikan pengaruh terhadap besar-kecilnya abrasi yang terjadi akibat energy gelombang di pantai. Berdasarkan hasil survey dilapangan menunjukkan bahwa kondisi ekosistem terumbu karang masih dalam keadaan baik sehingga memberikan pengaruh yang signifikan terhadap kestabilan pantai dan dapat mencegah terjadinya abrasi.

Kategori gelombang yang sedang di lokasi sangat berhubungan erat dengan musim angin barat. Musim angin barat merupakan musim yang menyebabkan perairan memiliki gelombang kategori sedang sampai besar yang dilokasi khusus dan wilayah indonesia pada umumnya disamping itu, musim ini merupakan musim basah (hujan) di Indonesia dikarenakan angin yang bertiup saat ini adalah angin yang bergerak dari benoa Asia ke benoa Australia yang memiliki kelembaban udara yang tinggi (udara basah). Kondisi angin yang bertiup di permukaan perairan akan berpengaruh terhadap besar dan kecilnya gelombang yang terbentuk hal ini sesuai dengan pendapatnya Hutabarat dan Evans (1984) bahwa tipe angin yang mempengaruhi besar dan kecilnya gelombang yang terbentuk adalah tergantung kecepatan angin bertiup dipermukaan, sumber dimana angin sedang bertiup dan jarak Fetch (Fetch lenght).

Ketika musim angin barat, angin bertiup dari perairan samudera pasifik melewati permukan perairan Indonesia menuju samudera hindia dengan kecepatan yang mulai sedang hingga besar dengan kelembaban yang tinggi yang mempengaruhi bentuk gelombang yang terjadi di perairan Indonesia dengan demikian, gelombang yang terbentuk di perairan Indonesia pada umumnya dan lokasi penelitian pada khususnya akan sedang hingga besar. Oleh karena itu, untuk mendapatkan data gelombang yang representatif diperlukan pengukuran pada musim yang berbeda (musim angin timur) supaya gambaran kondisi perairan dapat dijadikan acuan dalam pengambilan keputusan untuk pengelolaan potensi sumberdaya lautan secara terpadu. Hal tersebut menurut Carter (1988), jika suatu muka barisan gelombang datang dan membentuk sudut miring terhadap garis pantai yang mempunyai kemiringan dasar landai dengan kontur-kontur kedalaman sejajar dengan pantai , maka muka gelombang akan berubah arah dan cenderung menjadi sejajar dengan garis pantai atau mengalami proses pembiasan. Selanjutnya arah perambatan gelombang berubah dengan berkurangnya kedalaman, sehingga dapat diamati bahwa muka gelombang cenderung sejajar dengan kedalaman. Hal ini disebabkan perubahan gelombang yang mengakibatkan perubahan kecepatan fasa gelombang. Bila keadaan pantai landai, ada kemungkinan bahwa gelombang 
tersebut tidak pecah tetapi pemantulan gelombang (refleksi)

\section{Pasang Surut}

2.3. Pengukuran Pasang surut di lokasi kajian di lakukan dengan mempertimbangkan karakteristik lokasi kajian dimana penempatan alat pengukur pasang surut dilakukan pada wilayah yang tidak terekspose udara pada saat surut terendah. Hasil pengukuran pasang surut selama 40 jam dapat dilihat pada

Gambar 5. Secara visual, pasut yang ada pada lokasi kajian memiliki tipe pasang surut campuran cencerung ganda yang berarti dalam 24 jam terjadi 2 kali pasang dan 2 kali surut. Pada lokasi kajian juga ditemukan bahwa tinggi pasut memiliki ketidaksamaan harian dimana ketinggian pasang yang pertama berbeda dengan pasang berikutnya. Hasil ini sesuai dengan hasil yang didapatkan pada pengukuran pasut yang dilakukan pada saat bulan Oktober 2015 dimana tipe pasng surut di Lombok utara bersifat Campuran cenderung ganda. Menurut Pariwono (2007) perairan timur Indonesia yang pada umumnya berupa laut dalam, menyebabkan tipe pasutnya didominasi oleh tipe campuran dominansi ganda. Tunggang pasut yang yang didapatkan pada lokasi kajian pada saat pengukuran adalah $0.76 \mathrm{~m}$, tunggang pasut ini kurang dari 2 meter sehingga sangat cocok untuk dijadikan sebagai lokasi pembangunan pelabuhan/dermaga. Namun perlu lagi dilakukan pengukuran selama 15 hari untuk mendapatkan tunggang pasut saat pasut purnama dan perbani sehingga rentang tunggang pasut maksimum dan minimum dapat diketahui.

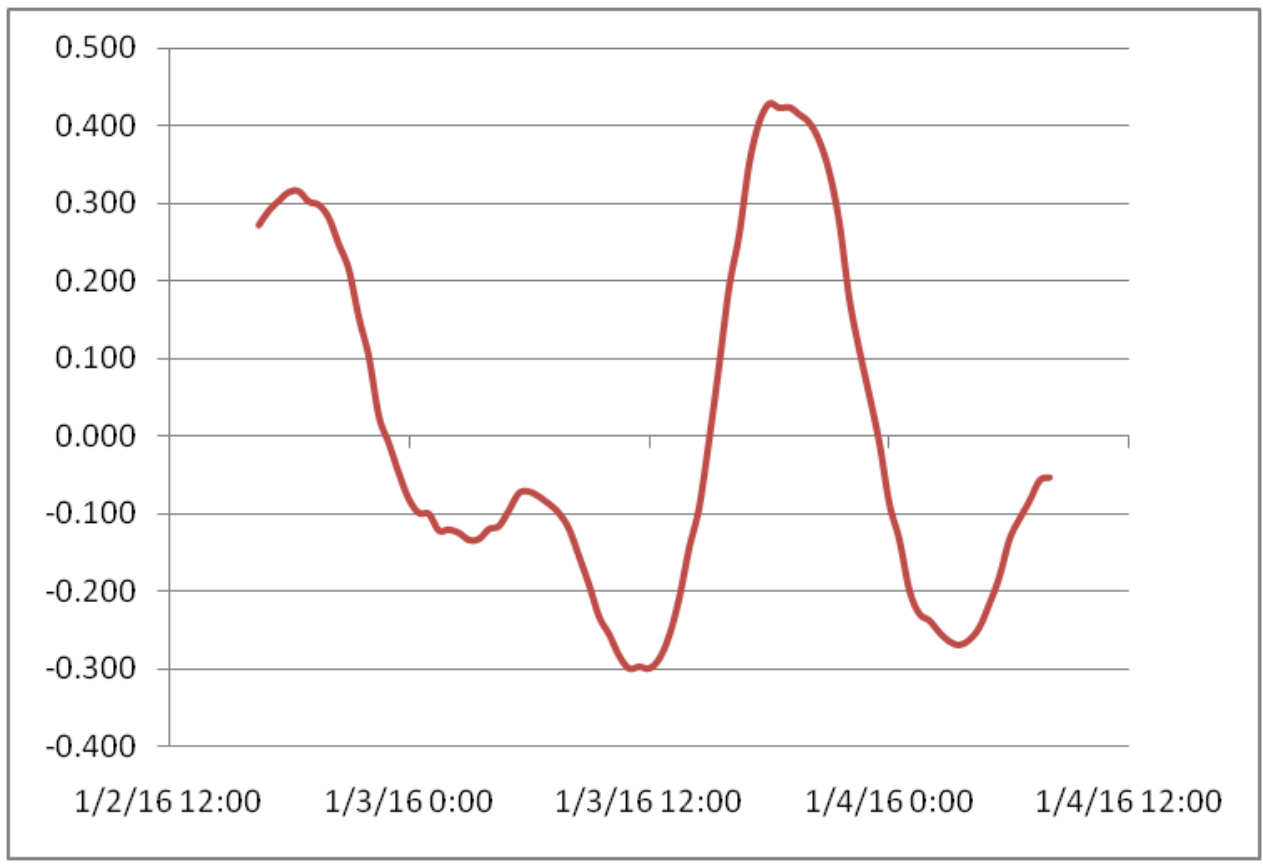

Gambar 6. Hasil pasang surut musim barat

\section{E. Kelayakan Dermaga PLTU}

Wilayah lokasi kajian menurut RZWP3K kabupaten lombok utara termasuk dalam kawasan strategi khusus Labuhan Carik. Dari segi aksesabilitas, maka wilayah kajian sangat mudah untuk diakses karena dilalui oleh jalan provinsi NTB rute Bayan-Lombok Timur. Wilayah ini hanya terletak sekitar $104 \mathrm{~km}$ dari Bandara Internasional Lombok (BIL) Praya dan hanya $89 \mathrm{~km}$ dari labuhan lembar yang merupakan pelabuhan Lombok - Bali. Selain itu 
dari pusat kota mataram, wilayah kajian hanya berjarak $73 \mathrm{~km}$ dan hanya berjarak $41 \mathrm{~km}$ dari pusat kota Kabupaten Lombok Utara. Sehingga secara umum aksesabilitas ke lokasi kajian sangat bagus baik dari darat, udara, maupun laut sehingga akan mempermudah dalam proses pengurusan administrasi.

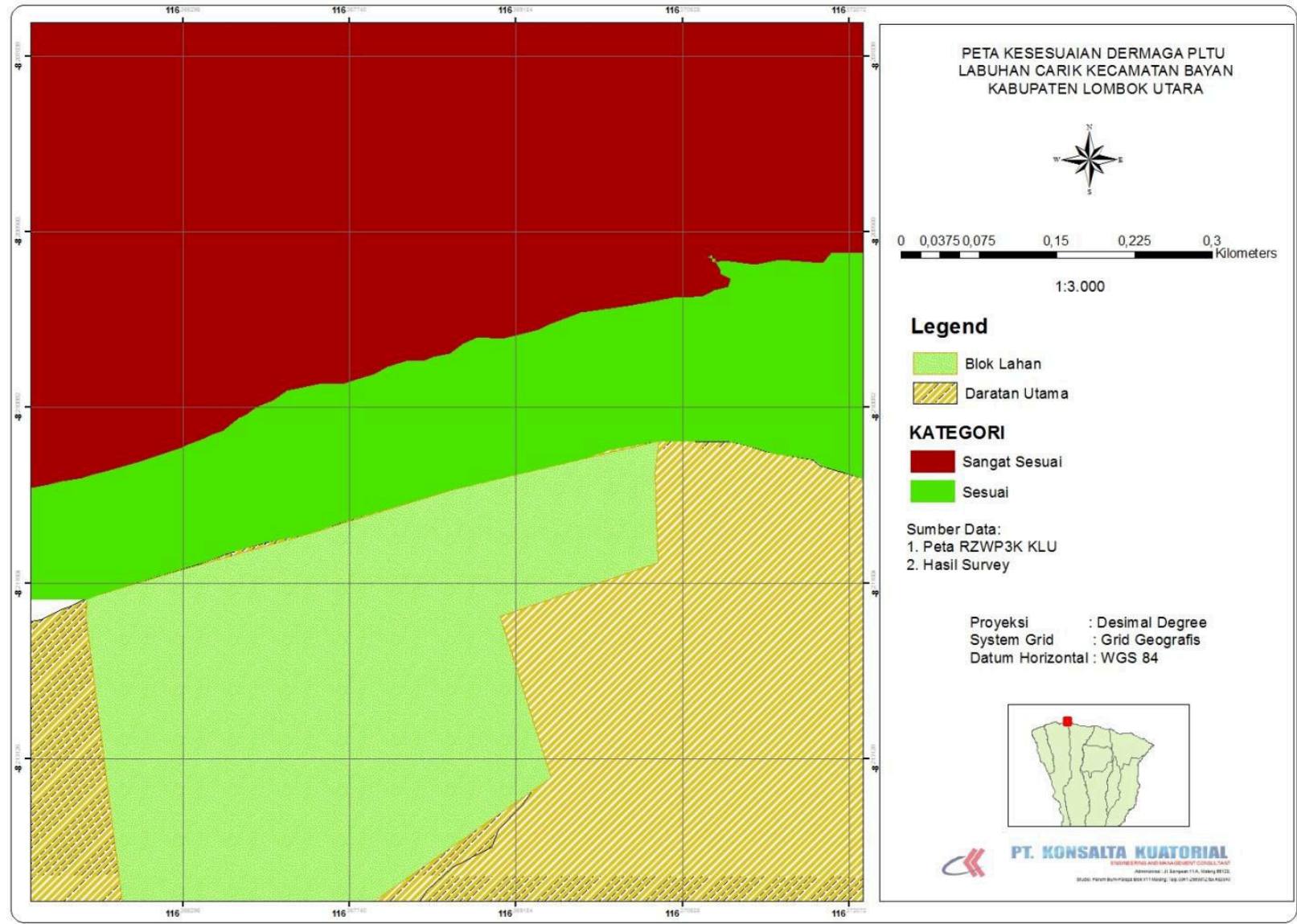

Gambar 7. Peta Kategori Kesesuaian Dermaga PLTU

\section{PENUTUP}

\section{A. Kesimpulan}

Berdasarkan hasil analisis data yang dilakukan dalam penelitian ini, maka dapat disimpulkan bahwa :

1. Potensi kesesuaian lahan wilayah perairan Bayan Lombok Utara untuk pembangunan/pengembangan dermaga PLTU memiliki tingkat kesesuaian yang berbeda-beda sesuai dengan karakteristik parameter lingkungannya.

2. Tingkat kesesuaian Lahan untuk pelabuhan/dermaga PLTU terdiri dari 2 kategori yaitu Sangat Sesuai (S1), dan Sesuai (S2).
B. saran

1. Untuk meningkatkan nilai penting dari suatu lahan pesisir sebaiknya dalam pemanfaatan dan pengembangannya harus memperhatikan faktor-faktor lingkungan yang menjadi daya dukungnya (carring capacity).

2. Perlunya perhatian khusus terkait faktor penentu keberhasilan pengembangan dan pemanfaatan potensi lahan seperti bentang alam (landscape) serta parameter yang lain seperti karakteristik oceanografi dan substrat dasar perairan sehingga membantu dalam perencanaan peruntukan kawasan pelabuhan sehingga nantinya dapat dikembangkan demi kebutuhan dan kesejateraan masyarakat pesisir sekitarnya, 
3. Pemerintah setempat harus memiliki acuan yang jelas dalam menentukan rencana penggunaan lahan wilayah pesisir supaya potensi yang ada termanfaatkan secara optimal demi kesejahteraan masyarakat serta mengurangi konflik kepentingan antar masyarakat,

4. Pemerintah setempat bersama pemerintah pusat harus menindaklanjuti rencana tata ruang wilayah pesisir selatan Lombok Utara sesuai peruntukkannya sehingga dapat meningkatkan pendapatan asli daerah yang berasal dari pemberdayaan wilayah pesisir dan lautan secara terpadu.

\section{DAFTAR PUSTAKA}

Bengen, D.G. 2000. Pedoman Teknis. Pengenalan dan Pengelolaan Ekosistem Mangrove. PKSPL-IPB. Bogor

2004. Sinopsis. Ekosistem dan Sumberdaya Alam Pesisir dan Laut Serta Prinsip Pengelolaannya. PKSPL-IPB. Bogor

Dahuri, R. J. Rais,. S.P. Ginting dan M.J. Sitepu. 1996. Pengelolaan Sumberdaya Wilayah Pesisir dan Lautan Secara Terpadu. PT. Pradya Paramita. Jakarta.

Dahuri, R., J. Rais, S.P.Ginting, dan M.J.Sitepu., 2004, Pengelolaan Sumberdaya Wilayah Pesisir dan Lautan Secara Terpadu (Edisi Revisi), PT. Pradnya Pratama, Jakarta.

Kramadibrata, S., $1985 . \quad$ Perencanaan Pelabuhan. Ganeca Exact.Bandung

Mappadjantji A., Andi. 2001. Penataan Ruang Wilayah Pesisir. Pustaka Ramadhan. Bandung.

Nontji, A., 1987. Laut Nusantara. Penerbit Djambatan. Jakarta.

Nybakken, J.W., 1992. Biologi Laut. Suatu Pendekatan Ekologis. Gramedia. Jakarta. 